\author{
V. Spadaro, A. S. Faqi \& P. Mazzola
}

\title{
Clinopodium raimondoi (Lamiaceae), a new species from Sicily
}

\begin{abstract}
Spadaro, V., Faqi, A. S. \& Mazzola, P.: Clinopodium raimondoi (Lamiaceae), a new species from Sicily. — Fl. Medit. 25 (Special Issue): 311-315. 2015. — ISSN: 1120-4052 printed, 2240-4538 online.

On the basis of the taxonomic study of the collections made by F. M. Raimondo, kept in PAL, a new species of Clinopodium is described. The new taxon, named Clinopodium raimondoi, occurs in N-W coast of Sicily on limestone substrata, in steppe communities dominated by Hyparrhenia hirta. The main distinctive characteristics of C. raimondoi, with respect to other taxa known from Europe and other Mediterranean countries, are the large size, the opposite and decussate branches, and the clearly woody at base stems of mature plants as well. Relationships of the new taxon with the Mediterranean ones in the $C$. nepeta group are also discussed.
\end{abstract}

Key words: Clinopodium, vascular plants, Mediterranean flora.

\section{Introduction}

In the last years, researches of pharmaceutical and phytochemical nature on wild Sicilian plant species of Clinopodium L. (Lamiaceae) have been carried out in the pharmaceutical biological Laboratory of the Palermo University. Firstly, in the research all the plant material, including that hard to be identified has been taxonomically characterized. From the taxonomical analysis, on the whole well known taxa belonging to the Sicilian flora, have been easily identified. Nevertheless, a population distinct from all taxa known in both Sicily and the whole Mediterranean area, spread along the northwestern coast has been found. On the basis of the morphological characters observed, the population in question is referred to an unpublished taxon which is here described and named Clinopodium raimondoi.

Clinopodium raimondoi Spadaro, A.S. Faqi \& Mazzola sp. nov. (Fig. 1)

Holotype: Palermo (Sicily): San Gabriele place, uncultivated fields on limestone soils, ca. 40 m s.l.m., 10.07.2014, Raimondo (PAL). Isotypes: PAL-Gr and FI.

Etymology: Name devoted to prof. Francesco Maria Raimondo, explorer of the Mediterranean flora, master, colleague and friend, in occasion of his $70^{\circ}$ birthday. 


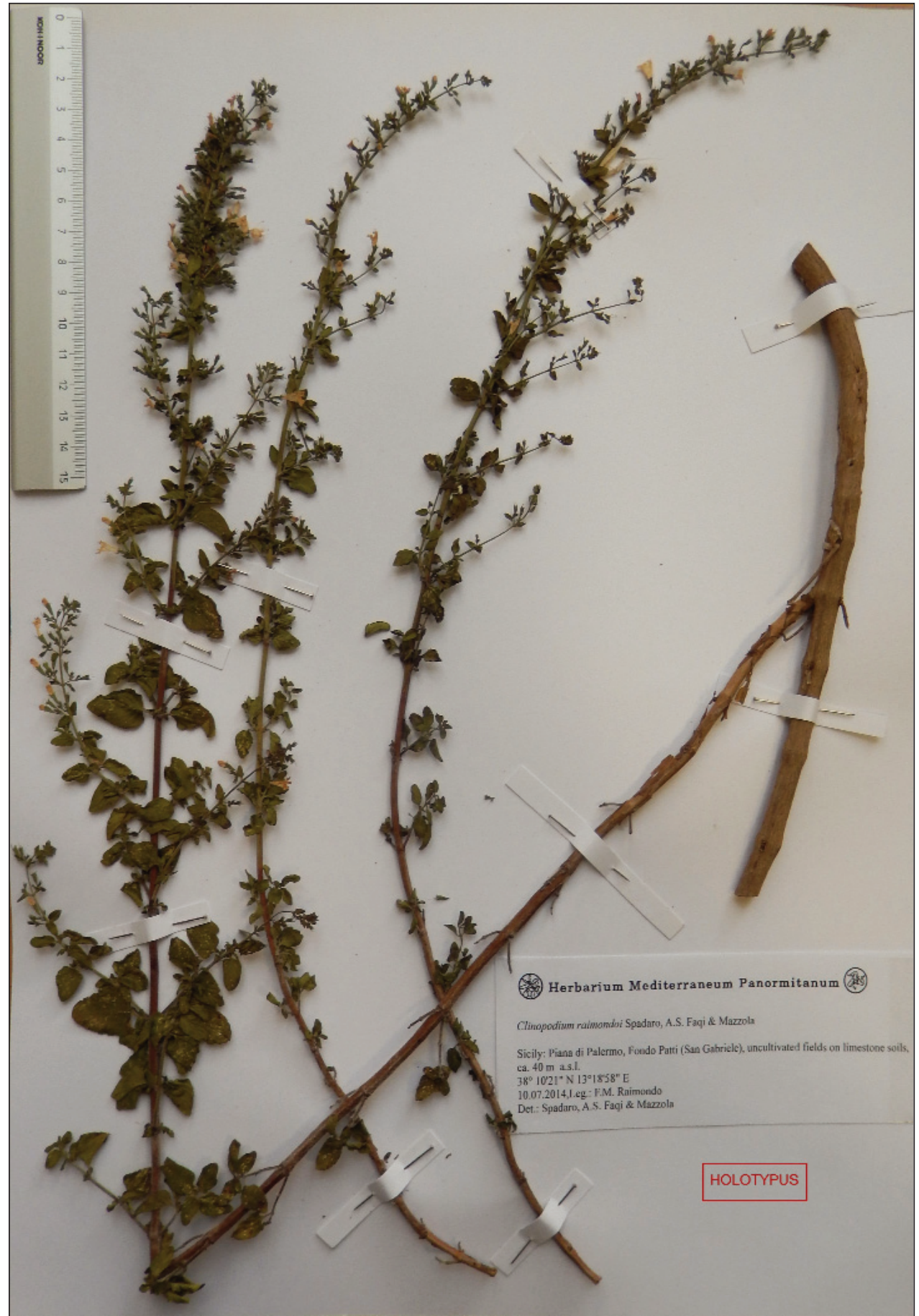

Fig. 1. The holotype of Clinopodium raimondoi in PAL. 
Diagnosis: Suffrutex caespitosus, 90-120 cm attingens. Caules validi prostrato-ascendentes, lignosi usque ad plus quam inferiorem dimidiam partem; superior dimidia pars pilosa. Rami secundi et tertii ordinis oppositi et decussati. Folia petiolata, plus minusve cordata; juvenia dense pilosa, senescentia sparsis pilis adpressis praedita. Calyx glandulosus, ciliolatus ad faucem; dentes inferiores trigoni, superiores longiores, lesiniformes. Corolla violacea vel plus minusve intense caerulea.

Description: Bushy aromatic plant, $90-120 \mathrm{~cm}$ high. Mature stems $8-12 \mathrm{~mm}$ in diameter at the base, woody up to above the middle part, hairy in the upper half. Branches and branchlets opposite, decussate. Leaves glandulose, petioled, slightly tooted-crenate at margins; young leaves hairy, mature leaves green, covered with sparse, short, appressed hairs on both blades. Flowers 2-7, shortly pedicellate; in numerous verticillasters (5-20); calyx glandulose, (2.5) 3 (3.5) $\mathrm{mm}$, opening ciliolate inside, 3 teeth short, triangular; the remaining 2 much longer, lesiniform; corolla more or less intense violet in colour, (9) 10 (11) mm.

Fenology: Flowering period March to December. Fruiting April to December.

Biological form: Camaephyte caespitose (Ch caesp).

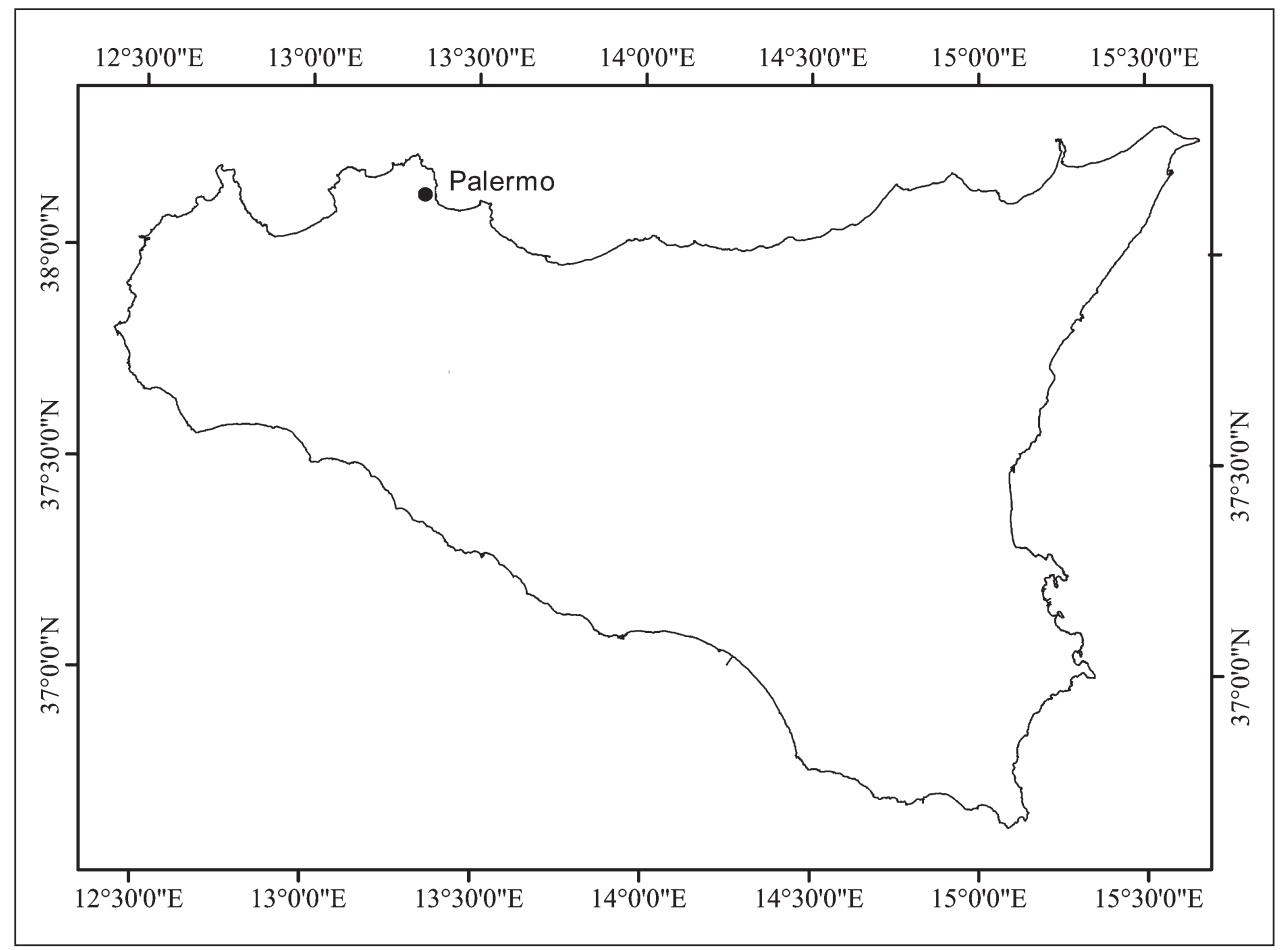

Fig. 2. Location of the locus classicus of Clinopodium raimondoi. 
Ecology and distribution: Species termophilous belonging to steppe plant communities dominated by Hyparrhenia hirta (L.) Stapf on limestone substrata. It occurs along the central-northern and probably also the southern coasts of Sicily (Fig. 2).

IUCN Status: Vulnerable.

\section{Taxonomic remarks}

From a traditional taxonomic point of view the new species should be included in the genus Calamintha founded by Miller (1754). As it is shown by the relevant synonymy, not always this taxon is accepted. Indeed species assigned to Calamintha Miller were also placed in Satureja L. (Fiori 1926; Pottier-Alapetite 1981; Greuter \& al. 1986).

Ball \& Getliffe (1972), Davis \& Lebeblici (1982), Siddiqi (1984), Ubera (1987), Morales Valverde (2011) and, as far as Italy, Sicily, Corsica and Sardinia are concerned, Pignatti (1982), Conti \& al.(2005), Giardina \& al. (2007), Jeanmonod \& Gamisans (2007) and Arrigoni (2013) accepted Calamintha Miller and included there several species, differing in number, mostly occurring in the Mediterranean area. This number variation, besides the size of the relevant distribution areas, depends especially on the different systematic approach followed by each taxonomist in delimiting each species and assigning discriminant values to the characters taken into account. Nevertheles Calamintha Miller, has recently been critically reviewed (Harley \& al. 2004), so that its specific and intraspecific taxa have been transferred to Clinopodium L. (Bräuchler \& al. 2006; Peruzzi \& Conti 2008; Bartolucci \& Conti 2011). Following this new systematic and taxonomic approach, the species described here has been placed under Clinopodium L. Thus, according Harley \& al. (2004) and Bräuchler \& al. (2005, 2006), the genus Calamintha Miller is to be included in Clinopodium L. (cfr. Peruzzi \& Conti 2008 and Bartolucci \& Conti 2011).

Owing to be woody at base and its calyx with asymmetrical teeth, Clinopodium raimondoi is related to $C$. nepeta (L.) Kuntze (= Calamintha nepeta (L.) Savi = Satureja calamintha (L.) Scheele $=$ C. officinalis Moench). Nevertheless, it is distinct by its larger size, stem hardy and more lignified, outside calyx and inner corolla lacking hairs. It is also similar to C. incanum L. [ = Calamintha incana (Sm.) Boiss.] from Greece, Turkey, Cyprus, Syria and North-Africa, by its larger size and woody stems, besides the sparse hairiness and cordate leaves with crenulate-toothed margin, not ovate-rounded with margin entire and revolute.

\section{Acknowledgments}

Support by the International Foundation Pro Herbario Mediterraneo is gratefully aknowledged.

\section{References}

Arrigoni, P. V. 2013: Calamintha. - Pp. 351-355 in: Flora dell'Isola di Sardegna, 4. - Sassari.

Ball, P. W., Getliffe, F. 1972: Calamintha Miller. - Pp. 166-167 in: Tutin, T. G., Heywood, V. H., Burges, N. A., Moore, D. M, Valentine, D. H., Walters, S. M., \& Webb, D. A. (eds.), Flora Europaea, 2. - Cambridge. 
Bartolucci, F. \& Conti, F. 2011: Notulae alla checklist della flora vascolare italiana 11. Novità nomenclaturali 1821. - Inform. Bot. Ital. 43(1): 143-144.

Bräuchler, C., Meimberg, H., Abele, T. \& Heubl, G., 2005: Polyphyly of the genus Micromeria Benth. (Lamiaceae) evidence from cpDNA sequence data. - Taxon 54: 639-650.

-, Meimberg, H. \& Heubl, G. 2006: New names in Old world Clinopodium -the transfer of the species of Micromeria sect. Pseudomelissa to Clinopodium. - Taxon 55: 977-981

Conti, F., Abbate, G., Alessandrini, A. \& Blasi, C. 2005: An annotated checklist of the Italian vascular flora. - Roma.

Davis, P. H. \& Leblebici, E. 1982: Calamintha Miller. - Pp. 323-329 in: Davis P. H. (ed.), Flora of Turkey, 7. - Edimburg.

Fiori, A. 1926: Calamintha. - Pp. 44-47 in: Nuova Flora analitica d'Italia, 2. - Firenze.

Giardina, G., Raimondo, F. M. \& Spadaro, V. 2007: A catalogue of the plants growing in Sicily. Bocconea 20: 5-582.

Greuter, W., Burdet, H.M. \& Long, G.(eds.), 1986: Med-checklist, 3. - Genève.

Jeanmonod, D. \& Gamisans, J., 2007: Calamintha. - Pp. 646-647 in: Flora Corsica. - Aix-enProvence.

Harley, R. M., Atkins, S., Budantsev, A. L., Cantino, P. D., Conn, B. J., Grayer, R., Harley, M. M., de Kok, R., Krestovskaja, T., Morales, R., Paton, A. J., Ryding, O. \& Upson, T. 2004: Labiatae. - Pp.167-275 in: Kubitzki, K. \& Kadereit, J. W. (eds.), The families and genera of vascular plants, 7. - Berlin \& Heidelberg.

Miller, P. 1754: The Gardenerers Dictionary, ed. 4. - London.

Morales Valverde, M. 2011: Calamintha Miller - P. 1355 in: Blanca, G., Cabezudo, B., Cueto, M., Salazar C. \& Morales Torres, C. (eds.), Flora Vascular de Andalucía Oriental, 2 ed.- Granada.

Peruzzi, L. \& Conti, F. 2008: Notulae alla checklist della flora vascolare italiana. 6. Novità nomenclaturali 1524-1529. - Inform. Bot. Ital. 40(2): 263-264.

Pignatti, S.,1982: Calamintha - Pp. 482-483 in: Flora d'Italia, 2. - Bologna.

Pottier-Alapetite, G. 1981: Calamintha. - Pp. 805-808 in: Flore de la Tunisie (Gamopetales), 2. Tunis.

Siddiqi, M. A., 1984: Lamiaceae. - Pp. 1-116 in: Jafri, J. M. H. \& Al-Gadi, E. (eds.), Flora of Libya, 118. - Tripoli.

Ubera, J. 1987: Calamintha Miller - Pp. 436-437 in: Valdés, B., Talavera, S. \& Fernández-Galiano, E. (eds.), Flora Vascular de Andalucía Occidental, 2. - Barcelona.

Addresses of the authors:

Vivienne Spadaro ${ }^{1}$, Ali Said Faqi ${ }^{2}$ \& Pietro Mazzola ${ }^{3}$,

${ }^{1}$ Dipartimento STEBICEF, Università di Palermo, via Archirafi, 38. - 90123

Palermo, Italy. E-mail: vivienne.spadaro@unipa.it

${ }^{2}$ Wayne State University, School of Medicine, Department of OBGYN, Detroit, Michigan, USA. E-mail: alifaqi@yahoo.com

${ }^{3}$ Dipartimento SAF, Università di Palermo, via Archirafi, 38. - 90123 Palermo, Italy.

E-mail: pietro.mazzola@unipa.it 
